\title{
Mortality from alcohol related disease in Italy
}

\author{
CARLO LA VECCHIA ${ }^{1}$, \\ AND CESARE CISLAGHI \\ ADRIANO DECARLI ${ }^{2,3}$, GUERRINO MEZZANOTTE ${ }^{1,2}$, \\ From "Mario Negri" Institute for Pharmacological Research,' via Eritrea 62, 20157 Milan, Italy; Institute of \\ Medical Statistics, ${ }^{2}$ University of Milan, National Cancer Institute, Via Venezian 1, 20133 Milan, Italy; and \\ Institute of Statistics, ${ }^{3}$ University of Trento, Via Verdi 26, 38100 Trento, Italy
}

SUMMARY Trends in death certification rates from the five major alcohol related causes of death in Italy (cancers of the mouth or pharynx, oesophagus, larynx, liver and cirrhosis of the liver) were analysed over a period (1955-79) in which per capita alcohol consumption almost trebled. Age standardised mortality from liver cirrhosis almost doubled in males and increased over $70 \%$ in females. In males, mortality from cancers of the upper digestive or respiratory tract showed increases of between $27 \%$ and $44 \%$, and liver cancer increased by over $100 \%$. In the late 1970 s, the four alcohol related cancer sites accounted for about $12 \%$ of all cancer deaths in males and $4.5 \%$ in females. Mortality from liver cirrhosis alone accounted for $4.8 \%$ of all deaths in males $\mathbf{( 9 . 2 \%}$ of manpower years lost) and $2.3 \%$ in females (6.3\% manpower years lost) in females. These figures were even higher in selected areas of north eastern Italy, where alcohol consumption is greater. In absolute terms, the upward trends observed correspond to about 10000 excess deaths per year in the late 1970s compared with rates observed two decades earlier and are thus second only to the increase in tobacco related causes of death over the same calendar period.

Although it is known that alcohol consumption in Italy has been traditionally high, ${ }^{1}$ the extent to which it has risen over the last few decades is probably less appreciated: between 1950 and 1980 , in fact, national per capita consumption values rose over threefold. ${ }^{2,3} \mathrm{~A}$ major difficulty in assessing the health consequences of changes in alcohol consumption in Italy arises from the pattern of drinking, which chiefly involves long term heavy drinking, "binges" being relatively infrequent. Not surprisingly, therefore, only about 350 deaths per year in the late 1970s were certified as due to "alcoholism" and 50 to "alcoholic psychosis". 4

Diseases and deaths related to constant heavy drinking each day are in fact much more frequent. In the late 1970s over 20000 death certifications per year were due to liver cirrhosis and over 10000 to the alcohol related cancer sites (mouth or pharynx, oesophagus, larynx, and liver), ${ }^{5}$ out of a total of about 500000 deaths per year in the whole of Italy. ${ }^{4}$

In the present study, national trends in mortality rates from the major alcohol related causes of death over the period 1955-79 are presented, and changes in rates within different geographical areas are discussed.

\section{Materials and methods}

Death certification numbers in the whole of Italy for the causes of interest, stratified for sex and age in five-year groups, were abstracted from publications by the Italian Central Institute of Statistics (ISTAT), available from 1955 onwards. ${ }^{6}$ There were no major changes in the definition or coding of the causes of death considered between the Seventh, Eighth and Ninth Revisions of the International Classification of Diseases (ICD, table 1). Estimates of the resident population were obtained from publications by the Department of Demography of the University of

Table 1 Codes of the International Classification of Diseases (ICD) included in each category of neoplasms considered

\begin{tabular}{llll}
\hline Type of cancer & 7 th ICD & 8 th ICD & 9 th ICD \\
\hline Mouth or pharynx & $140-148$ & $140-149$ & $140-149$ \\
Oesophagus & 150 & 150 & 150 \\
Larynx & 161 & 161 & 161 \\
Liver & $155 \cdot 0+155.8$ & 155 & 155.0 \\
\hline
\end{tabular}


Rome (for the period $1955-72),{ }^{7}$ and by the Central Institute of Statistics from 1972 onwards. ${ }^{8}$ On the basis of these data, age specific and age standardised mortality rates were computed, age standardisation being performed by the direct method using the 1971 census population (subdivided in five year age groups) as standard.

Copies of original computer tapes were also obtained from the ISTAT with extracts of all primary death records for the period 1975-77, since on the basis of published material death certification numbers are not available stratified simultaneously for age, sex, and province. From these data age specific directly standardised mortality rates and standardised mortality ratios from the causes of interest in each of the 95 Italian provinces were computed.

\section{Results}

Age standardised, truncated 35-64 years death certification rates from the four alcohol related cancer sites and liver cirrhosis in the whole of Italy over the period 1955-79 are reported in table 2. In males, mortality from cancers of the mouth or pharynx, oesophagus and larynx showed increases of between $27 \%$ and $44 \%$, and mortality from primary cancer or cirrhosis of the liver roughly doubled. In females, death certification rates from cancers of the mouth or pharynx, larynx or oesophagus were appreciably lower than in males and showed no consistent trend. There was a moderate upward trend in mortality from cancer of the liver and an over $70 \%$ increase for liver cirrhosis.

In the late 1970s, the four alcohol related cancer sites accounted for about $12 \%$ of all cancer deaths in males and $4.5 \%$ in females (overall, $8 \cdot 8 \%$ ). Mortality from liver cirrhosis alone accounted for $4.8 \%$ of all deaths in males and $2.3 \%$ in females. These proportions rose to $9 \cdot 2 \%$ for males and $6 \cdot 3 \%$ for females when manpower years lost (between the ages of 25 and 65) were computed. Overall the five alcohol related causes considered accounted for about $6 \%$ of all deaths.

When age-specific death certification rates from liver cirrhosis were considered (table 3), the upward trends were much more marked in the younger age

Table 2 Age standardised Italian death certification rates / 100000 people aged 35-64 from selected alcohol-related diseases

\begin{tabular}{|c|c|c|c|c|c|c|c|c|}
\hline \multirow[t]{2}{*}{ Cause of death } & \multirow[t]{2}{*}{ Sex } & \multicolumn{5}{|c|}{ Rates/100 000 people aged $35-64$ for: } & \multicolumn{2}{|c|}{ Rate of change 1955-79 } \\
\hline & & $1955-59$ & $1960-64$ & $1965-69$ & $1970-74$ & $1975-79$ & $\begin{array}{l}\text { Absolute } \\
\text { change }\end{array}$ & $\begin{array}{l}\text { Percent } \\
\text { change / } y r^{*}\end{array}$ \\
\hline $\begin{array}{l}\text { Cancer of mouth } \\
\text { or pharynx }\end{array}$ & $\begin{array}{l}\mathbf{M} \\
\mathbf{F}\end{array}$ & $\begin{array}{l}6.78 \\
1.50\end{array}$ & $\begin{array}{l}7 \cdot 18 \\
1 \cdot 55\end{array}$ & $\begin{array}{l}7 \cdot 34 \\
1 \cdot 53\end{array}$ & $\begin{array}{l}7.54 \\
1.47\end{array}$ & $\begin{array}{l}7 \cdot 53 \\
1 \cdot 38\end{array}$ & $\begin{array}{l}+0.75 \\
-0.12\end{array}$ & $\begin{array}{l}+0.5 \\
-0.4\end{array}$ \\
\hline $\begin{array}{l}\text { Cancer of } \\
\text { oesophagus }\end{array}$ & $\begin{array}{l}\mathbf{M} \\
\mathbf{F}\end{array}$ & $\begin{array}{l}5 \cdot 27 \\
1 \cdot 43\end{array}$ & $\begin{array}{l}5 \cdot 71 \\
1 \cdot 47\end{array}$ & $\begin{array}{l}5.86 \\
1.40\end{array}$ & $\begin{array}{l}5 \cdot 89 \\
1 \cdot 38\end{array}$ & $\begin{array}{l}6.13 \\
1.43\end{array}$ & +0.86 & +0.8 \\
\hline $\begin{array}{l}\text { Cancer of } \\
\text { larynx }\end{array}$ & $\begin{array}{l}\mathbf{M} \\
\mathbf{F}\end{array}$ & $\begin{array}{l}5 \cdot 23 \\
0 \cdot 45\end{array}$ & $\begin{array}{l}6.21 \\
0.52\end{array}$ & $\begin{array}{l}7 \cdot 38 \\
0.48\end{array}$ & $\begin{array}{l}8.23 \\
0.51\end{array}$ & $\begin{array}{l}8.48 \\
0.54\end{array}$ & $\begin{array}{l}+3.25 \\
+0.09\end{array}$ & $\begin{array}{l}+2.4 \\
+0.9\end{array}$ \\
\hline $\begin{array}{l}\text { Cancer of } \\
\text { liver }\end{array}$ & $\begin{array}{l}\mathbf{M} \\
\mathbf{F}\end{array}$ & $\begin{array}{l}2 \cdot 40 \\
2 \cdot 33\end{array}$ & $\begin{array}{l}3 \cdot 10 \\
2 \cdot 70\end{array}$ & $\begin{array}{l}3.47 \\
2.92\end{array}$ & $\begin{array}{l}4.09 \\
2.95\end{array}$ & $\begin{array}{l}5 \cdot 37 \\
3 \cdot 61\end{array}$ & $\begin{array}{l}+2.97 \\
+1.28\end{array}$ & $\begin{array}{l}+4 \cdot 0 \\
+2 \cdot 2\end{array}$ \\
\hline Liver cirrhosis & $\begin{array}{l}\mathbf{M} \\
\mathbf{F}\end{array}$ & $\begin{array}{l}25 \cdot 00 \\
10 \cdot 17\end{array}$ & $\begin{array}{l}31 \cdot 37 \\
12 \cdot 11\end{array}$ & $\begin{array}{l}39 \cdot 07 \\
14 \cdot 79\end{array}$ & $\begin{array}{l}45 \cdot 16 \\
17 \cdot 18\end{array}$ & $\begin{array}{l}47 \cdot 36 \\
18 \cdot 56\end{array}$ & $\begin{array}{l}+22 \cdot 36 \\
+8 \cdot 39\end{array}$ & $\begin{array}{l}+3 \cdot 2 \\
+3 \cdot 0\end{array}$ \\
\hline
\end{tabular}

*Average annual rate of change, assuming that the change has been linear and approximated as $100 \% \times$ difference in loge rates divided by 20 years.

Table 3 Age specific Italian death certification rates/100 000 people of selected age groups from liver cirrhosis

\begin{tabular}{|c|c|c|c|c|c|c|c|c|}
\hline \multirow[t]{2}{*}{ Sex } & \multirow[t]{2}{*}{ Age group } & \multicolumn{5}{|c|}{ Rates/I(X) o(K) people for: } & \multicolumn{2}{|c|}{ Rate of change 1955-79 } \\
\hline & & 195559 & 196064 & 196569 & 197074 & 197579 & $\begin{array}{l}\text { Absolute } \\
\text { change }\end{array}$ & $\begin{array}{l}\text { Percent } \\
\text { change /yr* }\end{array}$ \\
\hline Males & $\begin{array}{ll}35 & 44 \\
45 & 54 \\
55 & 64 \\
65 & 74\end{array}$ & $\begin{array}{r}8 \cdot 73 \\
33 \cdot 16 \\
83 \cdot 23 \\
125 \cdot 12\end{array}$ & $\begin{array}{r}12.86 \\
42.11 \\
98.93 \\
157.63\end{array}$ & $\begin{array}{r}19.41 \\
54.09 \\
119.73 \\
185.20\end{array}$ & $\begin{array}{r}24.51 \\
68 \cdot 11 \\
133.00 \\
202.76\end{array}$ & $\begin{array}{r}24 \cdot 63 \\
74 \cdot 18 \\
140 \cdot 86 \\
208 \cdot 50\end{array}$ & $\begin{array}{l}+15.90 \\
+41.02 \\
+57.63 \\
+83.38\end{array}$ & $\begin{array}{l}+5.2 \\
+4.0 \\
+2.6 \\
+2.6\end{array}$ \\
\hline Females & $\begin{array}{ll}35 & 44 \\
45 & 54 \\
55 & 64 \\
65 & 74\end{array}$ & $\begin{array}{r}3.14 \\
11 \cdot 5 x \\
27 \cdot 11 \\
39.73\end{array}$ & $\begin{array}{r}4 \cdot 21 \\
1.3 \cdot 28 \\
31 \cdot 84 \\
4 \times \cdot 105\end{array}$ & $\begin{array}{r}6.06 \\
16.99 \\
36.40 \\
57.84\end{array}$ & $\begin{array}{r}7 \cdot 20 \\
19 \cdot 47 \\
40 \cdot 03 \\
65 \cdot 16\end{array}$ & $\begin{array}{r}8.06 \\
20 \cdot 73 \\
43.90 \\
70 \cdot 42\end{array}$ & $\begin{array}{l}+4.92 \\
+9.15 \\
+16.79 \\
+30.69\end{array}$ & $\begin{array}{l}+4.7 \\
+2.9 \\
+2.4 \\
+2.9\end{array}$ \\
\hline
\end{tabular}

*Average annual rate of change. assuming that the change has been linear and approximated as $100 \% \times$ difference in loge rates divided by 20 years. 
Table 4 Age specific Italian death certification rates/100000 males of selected age groups from cancers of the mouth or pharynx and oesophagus

\begin{tabular}{|c|c|c|c|c|c|c|c|c|}
\hline \multirow[t]{2}{*}{ Cause of death } & \multirow[t]{2}{*}{ Age group } & \multicolumn{5}{|c|}{ Rates/100 000 males for: } & \multicolumn{2}{|c|}{ Rate of change 1955-79 } \\
\hline & & $1955-59$ & $1960-64$ & $1965-69$ & $1970-79$ & $1975-79$ & $\begin{array}{l}\text { Absolute } \\
\text { change }\end{array}$ & $\begin{array}{l}\text { Percent } \\
\text { change/yr* }\end{array}$ \\
\hline $\begin{array}{l}\text { Cancer of } \\
\text { mouth or pharynx }\end{array}$ & $\begin{array}{l}35-44 \\
45-54 \\
55-64 \\
65-74\end{array}$ & $\begin{array}{r}1.11 \\
5.52 \\
17.71 \\
35.52\end{array}$ & $\begin{array}{r}1.38 \\
6.07 \\
18.91 \\
36.88\end{array}$ & $\begin{array}{r}1.93 \\
7.05 \\
19.27 \\
36.66\end{array}$ & $\begin{array}{r}2 \cdot 14 \\
8 \cdot 74 \\
19 \cdot 74 \\
34 \cdot 67\end{array}$ & $\begin{array}{r}2.32 \\
11 \cdot 06 \\
22.26 \\
32.63\end{array}$ & $\begin{array}{l}+1.21 \\
+5.54 \\
+4.55 \\
-2.89\end{array}$ & $\begin{array}{l}+3.7 \\
+3.5 \\
+1.1 \\
-0.4\end{array}$ \\
\hline $\begin{array}{l}\text { Cancer of } \\
\text { oesophagus }\end{array}$ & $\begin{array}{l}35-44 \\
45-54 \\
55-64 \\
65-74\end{array}$ & $\begin{array}{r}0.60 \\
3.90 \\
14.86 \\
31.41\end{array}$ & $\begin{array}{r}0.42 \\
4.04 \\
15.38 \\
35.06\end{array}$ & $\begin{array}{r}0.93 \\
4.18 \\
15.50 \\
33.07\end{array}$ & $\begin{array}{r}1.00 \\
5.01 \\
16.10 \\
31.91\end{array}$ & $\begin{array}{r}1 \cdot 10 \\
6 \cdot 71 \\
17 \cdot 26 \\
29.92\end{array}$ & $\begin{array}{l}+0.50 \\
+2.81 \\
+2.40 \\
-1.49\end{array}$ & $\begin{array}{l}+3.0 \\
+2.7 \\
+0.7 \\
-0.2\end{array}$ \\
\hline
\end{tabular}

*Average annual rate of change, assuming that the change has been linear and approximated as $100 \% \times$ difference in loge rates divided by 20 years.

groups for both sexes. Steady rises, however, were also evident in middle and later age.

The pattern of age specific trends is different for cancers of the mouth or pharynx and oesophagus in males. As shown in table 4, in fact, large increases were observed in younger males, but mortality rates were roughly constant (or slightly downwards) in older age groups. When mortality rates were plotted against the central year of birth cohort ${ }^{9}$ (data not shown), decreases were evident for cohorts born between 1900 and 1915, followed by marked upward trends in subsequent cohorts. Quite interestingly in terms of alcohol related carcinogenesis, there was a marked fall (over $70 \%$ ) in per capita alcohol consumption (derived from trade and sale data ${ }^{2}$ in Italy between 1920 and 1935) followed by steady and marked increases later (fig. 1).

The geographical distribution of mortality from liver cirrhosis in various Italian provinces is shown in figure 2. Markedly elevated ratios in both sexes were observed in the north, chiefly in north eastern areas where alcohol consumption is greater. For instance, in the early 1970 s, per capita wine consumption estimated within a national household survey ${ }^{10}$ was 143, and 108 litres per year in the two major north eastern regions (Veneto and Friuli Venezia Giulia) as compared with a national average of 87 litres. For females, a few southern provinces showed elevated cirrhosis mortality ratios. This suggested, however indirectly, that causes other than alcohol consumption (ie, hepatitis B virus) may have a proportionally greater importance for females.

Analyses of the four alcohol related cancer sites, reported in a separate publication, ${ }^{11}$ produced largely comparable patterns for males (though somewhat less clearly for liver cancer). Consequently, for males significant positive correlations were evident between mortality rates from these causes in various Italian provinces, ranging from +0.38 between cancer of the larynx and liver cirrhosis and +0.71 between cancers of the oesophagus and larynx.

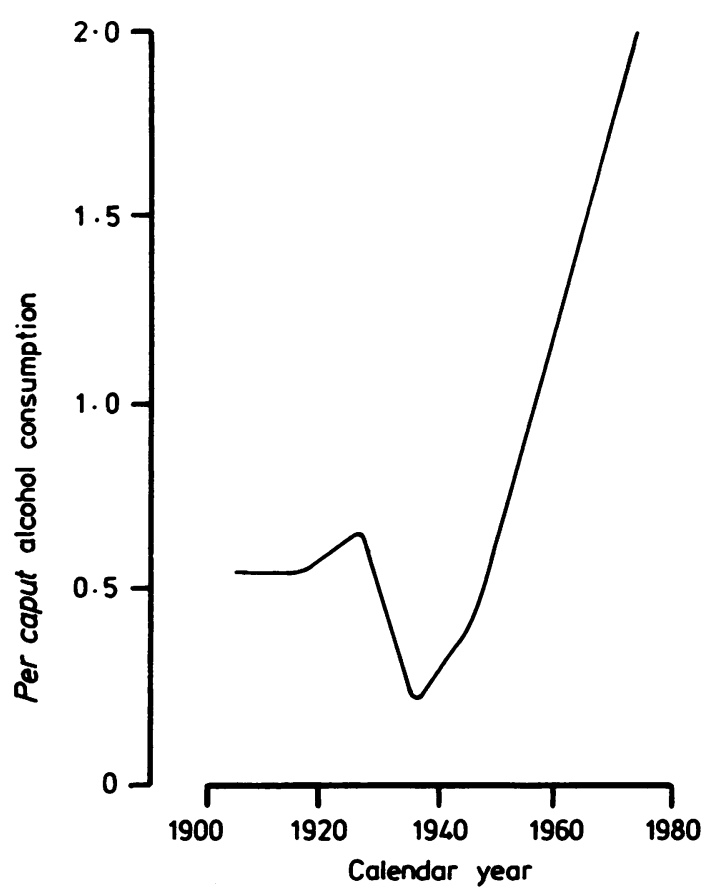

Fig 1 Trends in per capita total alcohol consumption in Italy (averaged to unity over the whole period).

\section{Discussion}

The findings of this analysis of trends in death certification rates from alcohol related diseases in Italy are extremely worrysome, since overall mortality from the five major alcohol related causes increased over $60 \%$ in both sexes between the late 1950 s and the late 1970s. In absolute terms, this corresponds to about 10000 more deaths per year in the later 1970s and is thus second only to the increase in tobacco related causes of death over the same calendar period. Alcohol related diseases represented a much larger 


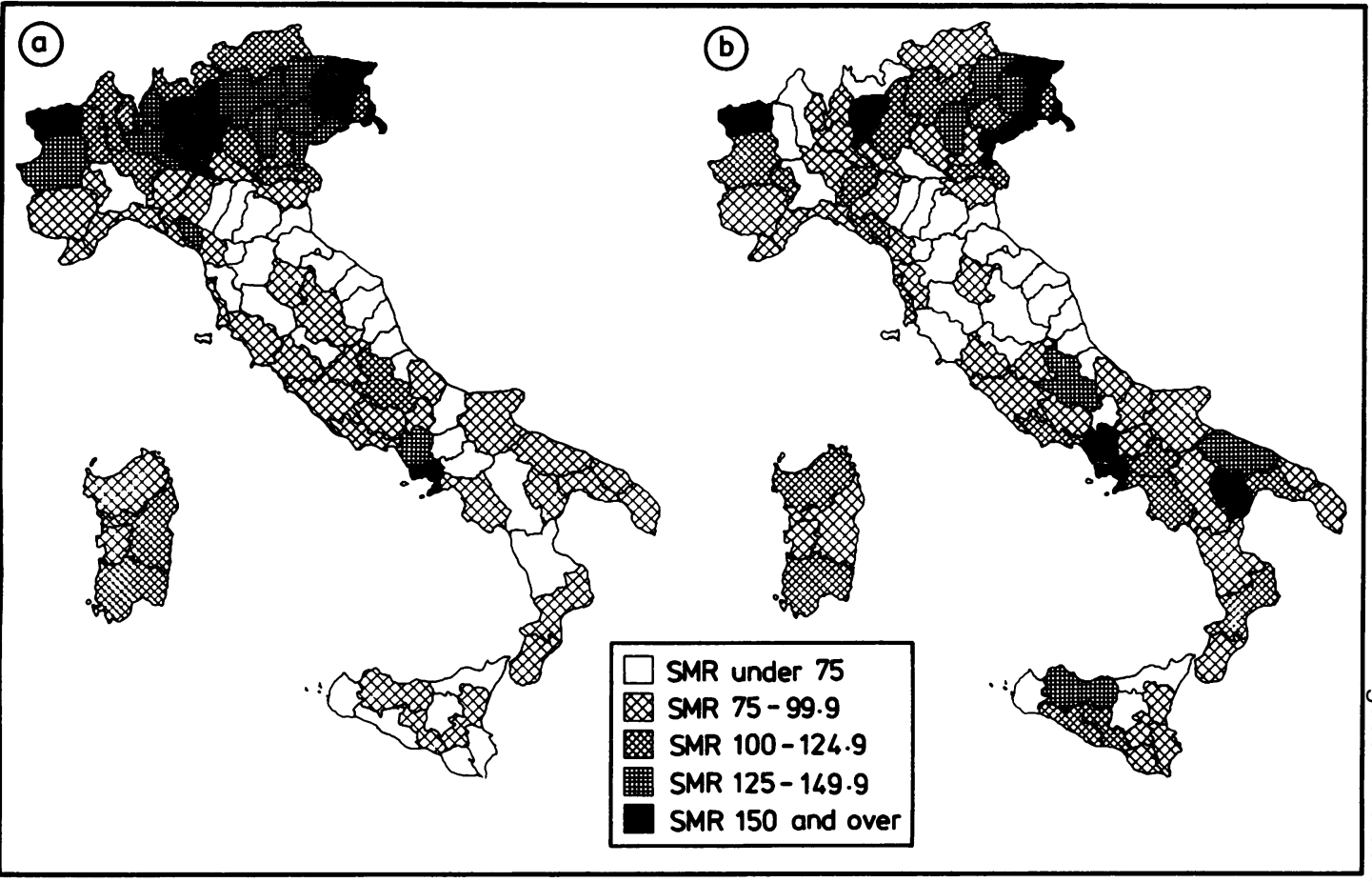

Fig 2 Standardised mortality ratios from liver cirrhosis in various Italian provinces, 1975-77: (a) males; (b) females.

proportion of all causes of deaths in Italy than in most other developed countries (with the sole exception of France) $)^{5,12}$ and, in particular, alcohol related neoplasms accounted for almost $9 \%$ of all cancer deaths.

There are, of course, several problems and uncertainties in the interpretation of the data presented. We tried to reduce bias related to the reliability of death certification by restricting our inferences on age standardised rates below age 65 and age specific ones below age 75 , and independent studies and analyses of comparative completeness have indicated that Italian death certification in these age groups is reasonably accurate for most causes of death. ${ }^{13}$ This may, however, not be the case for primary liver cancer, where misclassification may be common even in middle age. ${ }^{5}$

A major problem is posed by the fact that the diseases considered are caused by factors other than alcohol, chiefly tobacco for cancers of the mouth, pharynx, oesophagus or larynx and hepatitis B virus for cancer or cirrhosis of the liver. ${ }^{5,14-16}$ Since there is a positive interaction between alcohol and tobacco on the excess risk of neoplasms of the upper digestive and respiratory tract, ${ }^{16}$ it is difficult to estimate precisely the proportion of alcohol related excess deaths in the absence of tobacco. This interaction probably. accounts also for the large male/female differences in mortality from these neoplasms, since smoking (and, in particular, pipe or cigar smoking) was extremely uncommon in Italian females over past decades. ${ }^{17}$ However, alcohol alone has been proved carcinogenic on human oesophagus. ${ }^{18}$ Further, it is known that modification in exposure to only one of these two risk factors can markedly modify the excess risk for subjects exposed to both. ${ }^{5}$ Similar considerations may be applied to the interaction between alcohol and hepatitis B virus in cirrhosis or carcinoma of the liver. ${ }^{14,19}$

However complex the problems of interpretation, the data still indicate that mortality from all major alcohol related causes (whatever the influence of other aetiological factors) has largely increased in Italy during a period when average per capita alcohol consumption has roughly trebled. This finding is in general agreement with previous studies of trends in alcohol consumption and in mortality from various alcohol related causes in Britain or in Finland. ${ }^{20-22}$

Further evidence of an important role of alcohol in the mortality trends discussed is given by the 
inspection of age specific rates. In fact, marked upward trends were observed in mortality from all the alcohol related causes in young males, but death rates from cancers of the mouth or pharynx, oesophagus and larynx were declining for males born between 1900 and 1915, who were young adults in a period (between 1920 and 1935) when alcohol consumption was reduced in Italy. ${ }^{2}$ This indirectly indicates an early stage effect of alcohol on carcinogenesis of the upper digestive and respiratory tract. ${ }^{23}$

The geographical differences in mortality rates observed in various Italian provinces give additional evidence of a determinant role of alcohol, since mortality was grossly elevated in areas with higher alcohol consumption, ${ }^{10}$ and death certification rates from the major alcohol related causes were positively and (chiefly in males) strongly correlated. In some areas of north eastern Italy, deaths from liver cirrhosis alone accounted for over $18 \%$ of total years of work lost in males and about $10 \%$ of females (although the prevalence of serum heptatis B markers in the same areas was lower than the national average), ${ }^{24,25}$ and mortality rates from cancer of the oesophagus in males were over five times the national average ${ }^{11}$ and among the highest reported in western Europe. ${ }^{12}$ In summary, the evidence presented indicates that the health consequences of heavy alcohol drinking in Italy are extremely severe and have been markedly increasing over the last three decades, in line with a large increase in alcohol consumption.

This work was conducted within the framework of the CNR (Italian National Research Council) Applied Projects "Oncology" (Contract No. 85.02209.44) and "Preventive and Rehabilitative Medicine" (Contracts No. 84.02233.56 and No. 84.02299.56).

The contributions of the Italian Association for Cancer Research and of the Italian League against Tumours, Milan, Italy, are gratefully acknowledged.

We thank Dr Alessandro Barchielli for providing figures on alcohol consumption, Dr Eva Negri for skilful help with data processing, and the Gustavus A Pfeiffer Memorial Library and Ms Antonietta Di Bitetto for editorial assistance.

\section{References}

${ }^{1}$ Food and Agriculture Organization. Food balance sheets, 1964-66 average. Rome: FAO, 1971.

2 Istituto Centrale di Statistica. Sommario di statistiche storiche dell'Italia, 1961-1975. Rome: ISTAT, 1976.
${ }^{3}$ Istituto Centrale di Statistica. Annuariostatisticoitaliano. Rome, 1981.

${ }^{4}$ Istituto Centrale di Statistica. Annuario di statistiche sanitarie, vol. XXV, 1980. Rome: ISTAT, 1984.

${ }^{5}$ Doll $R$, Peto $R$. The causes of cancer: Quantitative estimates of avoidable risks of cancer in the United States today. JNCI 1981; 66: 1191-1308.

${ }^{6}$ Istituto Centrale di Statistica. Annuario di statistiche sanitarie,vol.I-XXXV,1955-1980.Rome:ISTAT,1958-84.

${ }^{7}$ Università degli Studi di Roma "La Sapienza". Ricostruzione della popolazione residente per sesso, età e regione, anni 1952-1972. Rome, 1983.

${ }^{8}$ Istituto Centrale di Statistica. Popolazione residente per sesso, età e regione. Bollettino Mensile di Statistica 1976; 10: Suppl. 1978; 11: suppl.

${ }^{9}$ Decarli A, La Vecchia C, Cislaghi C, Fasoli M, Mezzanotte G, Negri E. (Cancer mortality in Italy: effects of age, birth cohort and period of death.) La mortalità per tumori in Italia: Effetti dell'età, della generazione di nascita e del periodo di morte. Lega Italiana per la Lotta Contro i Tumori, Milano 1986.

${ }^{10}$ Istitutó Centrale di Statistica (ISTAT). Indagine campionaria sui consumi delle famiglie. Supplemento ordinario al bollettino mensile di statistica, no. 3, ISTAT, Roma 1975.

${ }^{11}$ Cislaghi C, Decarli A, Morosini P, Puntoni R. Atlante della mortalità per tumori in Italia. Triennio 1970-1972. Lega Italiana per la Lotta Contro i Tumori, Roma, 1978.

12 World Health Organization. World health statistics annuals. Geneva: WHO, 1981-84.

${ }^{13}$ Zanetti R, Viganò C, De Molli S, Colombo A, Cislaghi C. Comparative completeness and correspondence of cancer mortality data as collected by ISTAT and cancer registries. Tumori 1982; 68: 457-63.

14 Bréchot C, Nalpas B, Couroucé A-M, Duhamel G, Callard P, Carnot F, Tiollais P, Berthelot P. Evidence that hepatitis $B$ virus has a role in liver-cell carcinoma in alcoholic liver disease.. $N$ Engl J Med 1982; 306: 1384.

15 Saunders JB, Wodak AD, Morgan-Capner P, White YS, Portmann B, Davis $\mathbf{M}$, Williams $\mathbf{R}$. Importance of markers of hepatitis B virus in alcoholic liver disease. $\mathrm{Br}$ Med J 1983; 286: 1851-4.

16 Tuyns AJ, Péquignot G, Jensen OM. Le cancer de l'oesophage en Ille et Vilaine en fonction des niveaux de consommation d'alcool et de tabac. Des risques qui se multiplient. Bull cancer 1977; 64: 63-5.

${ }^{17}$ La Vecchia C. Patterns of cigarette smoking and trends in lung cancer mortality in Italy. $J$ Epidemiol Community Health 1985; 39: 157-64.

18 Tuyns AJ. Oesophageal cancer in non-smoking drinkers and in non-drinking smokers. Int $J$ Cancer 1983; 32:

19 Yu MC, Mack T, Hanisch R, Peters RL, Henderson BE, Pike MC. Hepatitis, alcohol consumption, cigarette smoking, and hepatocellular carcinoma in Los Angeles. Cancer Res 1983; 43: 6077-9.

${ }^{20}$ Smith R. Overture to the alcohol debate. Br Med J 1981; 282: 835-8.

${ }^{21}$ Smith $\mathbf{R}$. The relation between comsumption and damage. Br Med J 1981; 283: 895-8.

22 Doll R. Prospects for prevention. Br Med J 1983; 286: 445-53.

23 Day NE, Brown CC. Multistage models and primary prevention of cancer. JNCI 1980; 64: 977-89.

24 Pasquini P, Laurenzi M, Pons R, Pileggi D, Panà A. Nota sulla distribuzione geografica dei markers dell'epatite virale B in Italia. Igiene e Sanità Pubblica 1982; 38: 280-8.

${ }^{25}$ Pasquini P, Kahn HA, Pileggi D, Panà A, Terzi J, Guzzanti E. Prevalence of hepatitis B markers in Italy. Am J Epidemiol 1983; 118: 699-709. 